\title{
TEMPEH JUICE AS POTENTIAL HEALTH SUPPORT CULINARY TOURISM
}

\author{
I Gusti Ayu Ari Agung. \\ Mahasaraswati University Denpasar
}

\begin{abstract}
Tourism is part of the backbone the supports a country's economic life. According to that fact, Indonesia should have a special concern by building a strong branding for it's tourism. Tempeh juice culinary is one choice that has big potential to work out, because Indonesian's most type tourists, they will always have a need to fill the stomach. The goal of the promotion is to increase the number of Indonesia's foreign visitors, by giving impression and belief that tempeh juice as potential health has a unique, interesting, and cool sensation. Tempe is a traditional Indonesian food that are older than 1000 years. Tempeh is actually only be fermented in the area with warm temperatures such as in Indonesia. Promotion tempeh juice should be done consistently and continuously. The government is expected to be more creative in promoting tempeh juice health culinary, with the manufacture of various culinary travel guide books tempeh juice for health, in order to reach an increasing number of foreign tourists.
\end{abstract}

Keywords : Tempeh Juice, Culinary Tourism

\section{INTRODUCTION}

Today, the development of tourism in Indonesia, more widespread, the development of a wide range of facilities supporting tourism and hospitality are also increasingly rampant built, one of which is a restaurant. Food is a primary human needs that must be met in advance compared to other types of needs. In terms of travel, no matter what the destination of tourists coming to Indonesia, whether they enjoy nature, culture, attractions, or entertainment, there will be a need to eat. Seeing some of the tourism potential of Indonesia that is able to sell, in fact mutually supportive, the culinary selected as the main spearhead. This is because the culinary not able to be felt through the photos or videos, so people had to taste it directly in Indonesia (Astri Primasari, 2015).

The origin of tempeh, a traditional fermented soybean food, has been investigated. Tempeh dish has been served by Mataram people in the 1600's, so tempeh might be developed long before that time. In the past, tempeh was made from black soybean (Phaseolus niger) which was grown locally in Java. Among the non salted soybean fermentation in Asia, only tempeh prepared by mold (Rhizopus sp), the others are usually using bacteria. The technology of tempeh was inherited by Javanese people and closely related with their tradition and culture. Tempeh has been consumed by major in Indonesian population for more than 500 years and acknowledged as a national food. At present, tempeh is popular in the whole country and it was known all over the world (Kwon et al., 
2010; Mary Astuti, 1995; Yang et al., 2011). Tempeh is actually only be fermented in the area with warm temperatures such as in Indonesia (Gondosari, 2016).

Tempeh consumption is increasing. The increase might be due to the increase of population and per capita of consumption. New consumers are also growing, in other countries, e.g. : USA, Japan and the Nederlands. In Indonesia, the way of consuming tempeh is mostly in conventional way, as side dishes and snacks, cooked with traditional recipes. However, modern way of tempeh consumption will constantly increase affected by Western style (Kasmidjo, 1995).

\section{THE BENEFIT OF TEMPEH JUICE FOR HEALTH}

Changes in lifestyle of the people of the traditional lifestyle into a more modern lifestyle, also triggering changes in diet, particularly in the selection of food. Modern societies tend to choose foods that are practical and fast, so fast food is preferred over processed foods themselves. Fast food is superior in terms of practicality, but it has harmful effects on health. Fast food many contain unsaturated fats which can trigger the formation of free radicals (Kusumaningsih, 2007). In addition to the consumption of fast food, formation of free radicals is also triggered by the increase of pollutants due to the burning of a motor vehicle, cigarette smoke fund solar radiation. The free radicals can lead to various degenerative diseases such as diabetes, obesity, arthritis, hypertension, heart disease and atherosclerosis (Tapan, 2005). The damage caused by free radicals (oxidative damage) in the body basically can be overcome with the endogenous antioxidants in our body such as the enzyme catalase, glutathione peroxidase, superoxide dismutase and glutathione s-transferase, but if the amount of free radicals in the body increases, the necessary antioxidants from the outside. This can be overcome with foods high in antioxidants (Ari Agung, 2013).

The benefit of tempeh for health has been proved in several researches (Kusharyanto dan Agus Budiyanto, 1995). Tempeh is contain antioxidants (amino acid, isoflavon, niasin, estrogen, omega-3, lecithin, super oxide dismutase and vitamin E) compounds in the form of antioxidant that has a function as an agent of scavenger to free radicals caused oxidative stress. Some researchers reported that isoflavones act increased the antioxidant activity of superoxide dismutase (SOD). Tempeh isoflavones on potentially big impact on health, because of its ability as a catcher radical, that is by changing the superoxide radical, a reaction catalyzed by dismutasi. Many researchers reported that the catalase enzyme activity can be induced by the intake of antioxidants (beta carotene and isoflavones) (Harlinawati, 2006; Vedavanam et al., 1999; Winarsi, 2007).

Tempeh soy local varieties are highly nutritious, mainly protein (full contains eight kinds of essential amino acids, contain enough arginine and low methionine) and vitamin B12 as well as a source of antioxidants essential, such as unsaturated fatty acids plural (PUFA), minerals ( $\mathrm{Fe}, \mathrm{Cu}, \mathrm{Zn}, \mathrm{Se}$, and $\mathrm{Cr}$ ), vitamin B2 (riboflavin), vitamin E, isoflavones, SOD, and beta carotene. Excellence tempeh fresh else is safe to eat raw, in addition to having a texture unique mobile so easily digested, absorbed, tastes good, and savory, also contain substances that are efficacious antibiotics, ergosterol, phytoestrogens, hormones thyroxine and 
enzymes (protease, lipase, amylase and glycosidase, and increases good intestinal flora (Winarsi 2007; Marsdem 2008; Mindell, 2008).

Efficacy tempe for memory skills of the brain considered good once, as a result of this discovery, the American price of tempeh be expensive (Anonimus, 2009). Research results found that the provision of tempeh papaya juice in children with low levels of hemoglobin, can significantly improve hemoglobin levels, so that it can cope with anemia (Husnul Mar'ah, 2016). Tempeh, which known as Indonesian traditional fermented soybean, has a antidiabetic, antidislipidemic, antiatherogenic, antioxidant and antiinflammationbetter (Bintari et al., 2015; Hastuti, 2005; Kumar, 2007). Fresh tempeh has the highest benefit, when measured Benefits Index compared with other healthy foods are as follows (Gondosari, 2016) :

1. Antioxidants. Antioxidants from fruits and vegetables have the highest Benefits Index only +5 alone. While tempeh has a +15 Benefit Index.

2. Unsaturated Fatty Acids (Omega-3 and Omega-6). Known high content of omega-3 and omega- 6 are fish, avocado, and a VCO with Benefits Index +5 , so still less than tempeh with Benefits Index is +20 .

3. Healthy heart. Benefit Index of sapodilla $(+15)$, red apples $(+10)$, avocado $(+5)$, while omega-3 and omega-6 from fish $(+1)$. So tempeh still superior to nourish the heart, with the Benefit Index is +25

4. Healthy arteries and veins. Tempe helpful for cleaning deposits of cholesterol, because it contains unsaturated fatty acids. Tempe Benefits Index is +10 .

5. Protein and Carbohydrate Content of Energy. Protein Benefits Index is +5 , indicating fresh tempeh nourish the kidneys and does not produce uric acid.

Benefit Index carbohydrates is +5 , indicating fresh tempeh and healthy pancreas does not produce blood sugar

\section{CONCLUSION}

1. Tempe is a traditional Indonesian food that are older than 1000 years. Tempeh is actually only be fermented in the area with warm temperatures such as in Indonesia.

2. The goal of the promotion is to increase the number of Indonesia's foreign visitors, by giving impression and belief that tempeh juice as potential health has a unique, interesting, and cool sensation.

3. Promotion tempeh juice should be done consistently and continuously. The government is expected to be more creative in promoting tempeh juice health culinary, with the manufacture of various culinary travel guide books tempeh juice for health, in order to reach an increasing number of foreign tourists.

\section{REFERENCES}

Astri Primasari. 2015. Promosi Kuliner Lokal sebagai Daya Jual Pariwisata Indonesia untuk Backpacker Asing. Jurnal Tingkat Sarjana Bidang Seni Rupa dan Desain. Bandung. ITB. 
Bintari, SH., ND Putriningtyas, K. Nugrheni. 2015. Comparative Effect of Tempeh and Soymilk on Fasting Blood Glucose. Pakistan Journal of Nutrition 13 (4).

Hastuti, T. 2005. Faktor-Faktor Resiko Terbaru untuk Penyakit Kardiovaskular. Jakarta: Prodia.

Husnul Mar'ah. 2016. Pengaruh Pemberian Jus Tempe Pepaya terhadap Kadar Hemoglobin pada Anak-Anak Anemia. http://uin-makasar.academia.edu/ (Diakses 19 Juli 2016)

Kasmidjo, R. 1995. Teknologi Pembuatan Tempe sebagai Dasar Pengembangan Industri Tempe Modern. Proseding Simposium Nasional. Yayasan Tempe Indonesia. Jakarta.

Kumar, V., Cotran, R.S., Robbins, S.L. 2007. Patologi 1. Jakarta: Penerbit Buku Kedokteran.

Kusharyanto dan Agus Budiyanto. 1995. Upaya pengembangan Produk Tempe dalam Industri Pangan. Proseding Simposium Nasional. Yayasan Tempe Indonesia. Jakarta.

Kwon, DY., SM. Hong, IS. Asn, MJ. Kim, HJ. Yang, and S. Park. 2011. Isoflavonoids and Peptides frm Meju, Long-Term Fermented Soybeans Increase Insulin Sensitivity and Exert Insulinotropic Effects in Vitro.

Mary Astuti. 1995. Sejarah Perkembangan Tempe. Proseding Simposium Nasional. Yayasan Tempe Indonesia. Jakarta.

Vedavanam, K., Srijayanta, S., Reilly, J.O. 1999. Antioxidant Action and Potential Antidiabetic Properties of an Isoflavonoid - Containing Soybean Phytochemical Extract. Phytotherapy Research, 13.

Yang, B, Y. Chan, T. Xu, Y. Yu, T. Huang and X. Hu. 2011. Sytematic Review and meta-analysis of Soy Products Consumptions in Patients with Type 2 Diabetes Mellitus. Asia Pac. J. Clin. Nutr. 20. 